\title{
Partnerships Between Teacher Education Universities And Schools In Practicum To Train Pre-Service Teachers Of Vietnam
}

\author{
Vu Thi Mai Huong ${ }^{1}$, Nguyen Thi Thanh Tung ${ }^{1}$, Tieu Thi My Hong ${ }^{1}$, Duong Hai Hung ${ }^{1}$ \\ ${ }^{1}$ Hanoi National University of Education, Vietnam \\ Correspondence: Nguyen Thi Thanh Tung, Hanoi National University of Education, Vietnam, 136 Xuan Thuy Rd, \\ Cau Giay district, Hanoi city, Vietnam. Email: tungntt@hnue.edu.vn
}

Received: June 272020

Accepted: July 20, 2020

Online Published: July 20, 2020

doi:10.5430/ijhe.v9n5p134

URL: https://doi.org/10.5430/ijhe.v9n5p134

\begin{abstract}
Purpose

Teacher education universities and schools have traditionally been the main sites of teacher learning in Vietnam. This relationship is the key in the process national curriculum innovation. The purpose of this research is to determine the relationship between teacher education universities and schools in Vietnam, in regard to partnering for the delivery of teacher education adapting national curriculum innovation in Vietnam
\end{abstract}

\section{Method}

Data was collected through questionaries involving 243 participants comprising pre-service teachers, university lecturers and mentors. The result of this paper also uses semi-structured interviews to draw conclusions.

\section{Findings}

The findings show that there is a model for teacher education universities - schools cooperation in teacher preparation. However, the partnership is limited by such factors such as planning, mentoring, practicum program, communication between pedagogy universities and schools. The findings suggest that cooperation between pedagogical universities and schools can be promoted by mutually increasing awareness of the interdependence of relationships. The pedagogy universities and schools also need to diversify common areas of activity, especially to enhance dialogue on issues related to vocational training for pre-service students.

\section{Significance}

The results of the study provide insight into the factors that reduce the effectiveness of the partnership between pedagogical universities and schools, helping policy makers and educational managers have appropriate measures to develop the professionalism of teachers in high schools and help pre-service students prepare for future careers.

Keywords: practicum in Vietnam, partnership, mentor, pre -service teachers, teacher preparation

\section{Introduction}

Practicum is an important stage in the process of teacher training. This is the time for student teachers to come into direct contact with the lively realities of professional activities. Practicum helps them to consolidate, improve and expand the knowledge and skills being learned in pedagogical universities. Practicum is considered a test of the theoretical and practical preparation of student teachers for their independent work and the ability to solve the educational tasks of future teachers. Schools play an vital role in preparing pre-service teachers for the real world of the classroom (Kertesz \& Downing, 2016; Clarke, Triggs \& Nielsen, 2014; Keogh et al, 2006)

In recent years, there are different models of partnership between pedagogy universities and schools (Hobson, 2002; Halasz, 2016), however, school-based mentoring has become more and more popular. Schools have been increasingly important in teacher training. Collaboration between schools and universities is a natural relationship as "deliberately designed, collaborative arrangements between different institutions, working together to advance self-interest and solve common problems" (Hobson, 2002; Halasz, 2016). Effective practicums are constructed around genuine school-university partnerships where the responsibilities and roles of both school teachers and university lecturers are clearly defined, and where communication between these stakeholders is genuine, frequent, and meaningful. Practicum not only strengthens, complements and completes the pedagogical knowledge system being learned at the 
pedagogical university but also is an important assessment and preparation stage for future vocational of student teachers. It is process of educating and forming pedagogical career ideals in a realistic way. Therefore, Practicum is practice of student teachers and is conducted at schools. Direct personal mentoring is especially beneficial for pre -service students, helping them bridge the gap between theories and educational practices in schools. At the same time, counselors also help provide them with the skills to become professional teachers in the future (Singh \&Mahomed, 2013).

Kertesz \& Downing (2016) cited Thomson's study (2000) expressed that "Pedagogy is the main game of both teacher educators and school teachers, albeit situated in different sub-field, but the binary works to render relatively invisible their similar concerns, shared beliefs and pedagogical practices". The quality of professional development of graduates is directly proportional to the quality of the pedagogical training and development activities that they are involved in in the pedagogy universities. The process of participating in practical activities in schools determines a lot of the level of adaptation, meeting the common practical requirements of student teachers. In addition, schools always need the support of pedagogical universities in retraining and fostering teachers to meet the advocacy and development of education. According to My (2014), there are three methods of pedagogical practicum. They are Concentrated practicum, Semi - concentrated practicum and Unconcentrated practicum. However, the two modes 2 and 3 are essentially promoting the roles of high school in helping students to transform theory into educational practice associated with the types of teacher training.Vietnam's education is undergoing strong and fundamental innovations. Education activities in schools are having different changes compared to the previous period. Therefore, special attention must be paid to building a collaborative relationship between a pedagogical university and school for student teachers to have access to this innovative practice. The relationship between pedagogy universities and schools is extensively studied. This is a mutually beneficial relationship, a two-way bilateral relationship. In terms of practicum and training student teachers, this relationship connects students with educational practices and improves teacher training programs. The famous, high-ranking, traditional schools are traditionally chosen by the pedagogical universities to train pre - service students. The partnership in teacher training is generally geared towards meeting concerns about the quality of pedagogical students (Magudu \& Gumbo, 2018; Greany \& Brown, 2015; An, 2017).

In this article, we deeply analyze the meaning and situation of collaborative content between pedagogical universities and schools, in order to improve the quality of teacher training and retraining to meet the needs of innovation. Vietnam's education in the current period.

The research questions are:

Firstly, the importance of building collaborative relationships between pedagogical universities and schools in teacher training.

Secondly, the components of coordination between pedagogical universities and schools in teacher training.

\section{Literature Review}

"The concept of 'partnership' is defined and mutual benefits and challenges in partnerships with disciplines and institutions beyond teacher education programs are briefly discussed. Partnership is considered a breakthrough in teacher professionalization because it favors the articulation of the knowledge of the university and schools. Partnerships could be used as an emerging practice of collaboration, cooperation and sharing of responsibilities and commitments". (Smith, 2016; Foerste et al, 2017). The relationship between pedagogy universities and schools will help students approach honestly with educational practice. Because "While universities are situated at the heart of communities, particularly city com- munities, and have a similar capacity to contribute to community problem solving and civic renewal, Schools are the community institutions par excellence, and situated at the heart of community life both physically and socially" (Hartley \& Huddleston, 2010). The relationship between school and university is expressed in many fields, many different forms of which the most obvious is pedagogical practice. David \& Tony Yeigh in 2013 pointed that practicum is a way of bringing theoretical insights into the practices in the pre-service teacher education practicum. It also helps improve pre-servicec students' skills through the support of school mentors. Priorities in the relationship between the schools and the pedagogical universities include: Making student development a concern for schools, designing an internship program that demonstrates the relationship; Develop a common evaluation framework (Greany \& Brown, 2015).

This section will offer a brief background the role of partnerships in teacher education relating to practicum, method of partnership, components of partnerships in teacher education relating to practicum. 


\subsection{The Role of Partnerships in Teacher Education Relating to Practicum}

A number of researches around the world have been focusing on the partnership between pedagogy universities and schools in teacher training. Collaboration is strengthened by mutual commitment and responsibility. The main purpose of this relationship is to close the gap between theory and practice in teacher training. Through encouraging the cooperation process, it will lead to the development of pedagogical universities as well as schools, and improve teacher training programs. (Sigurdardóttir, 2010). Foerste et al (2017) considered "partnerships are required in teacher education, as a public policy, given the major economic and political transformations that occurred at the turn of the millennium and their demands for the educational field".

Practicum is an important activity in the training of knowledge, skills and education students. Because the process improves the quality of pre - service teachers, practicum is a compulsory stage, necessary conditions to form and develop pedagogical skills of teacher educators (Velzen \& Volman, 2008; Jones, 2008; Bezzina et al, 2006). Through that training, teacher educators have the opportunity to apply the theories to reality. At the same time, through practice at schools, they understand more about reasoning, supplementing theory. Bernadette (2006) pointed in this model student teachers learn theory at the university followed by practice in school. They spend time in teaching practice in real classrooms. There are numerours of aims to contribute to the professional development of classroom teachers through practicum at schools such as "Improving subject matter knowledge; Improving existing and introducing new instructional skills and strategies: Student teachers; Broadening the conception of their role as teachers; Increasing understanding of students and the learning process; Developing greater confidence in their own abilities as teachers and facilitating independent learning; Developing Professional Teacher" (Bernadette, 2006). The partnership between schools and pedagogy universities also provides information on how pedagogical universities organize practicum. This relationship shows the role of teachers and schools in this process. In particular, the role of schools focuse on developing the ability of teaching, relationship with learners and professionalism of pre-service students (Hill, 2008; Quick \& Siebörger, 2005).

Halasz (2016) expressed there are two main reasons related to establishing a partnership between schools and pedagogy universities. One side relating to train teacher educator, professional development and teacher learning. In the other hand, it is related to research, development and innovation. Concerning practicum, this relationship gives pre-service students the opportunity to participate in real-world problem solving, enriching their educational experience. Schools and Pedagogy universities is more and more closely linked through practicum. (Hartley \& Huddleston, 2010; Magudu \& Gumbo, 2018).

Magudu (2018) clarified that "this relationship between the key players in teacher education, though central in defining the outcomes of initial teacher education has often been considered lacking and superficial, especially in terms of integrating knowledge from both educational settings. Partnerships in teacher education generally evolved in response to concerns about the quality of student teachers' professional learning experiences while participating in pre-service teacher education programmes, which seemed to be provided out of context".

Clark (1999) delineated a series of beneficial outcomes from a successful partnership implementation. For schools, "partnership contribite to Enhance University involvement in community service; Reduce recruiting \& retention costs; Readily available resources for professional development. Furthermore, the partnership also effect on Pre-service Teachers such as: Coordination of pre-service \& in-service education; More familiar with practices required in schools; Preferred hiring status; Elicit better student participation than teachers assigned traditional internships; More quickly assume future leadership roles". At pedagogy university level, "they can improve the coordination of pre-service \& in-service education; Tuition and fees from in service; Veteran teachers select PDS university for future degrees; PDS-prepared teachers make better cooperating teachers for future". The combination of student teachers, clinical instructors, university faculties, and shared professional development activities greatly reduces teacher isolation and increases morale as they have regular opportunities for planning, brainstorming, and sharing with other professionals (Holen et al, 2014). There have also been a variety of more specific partnership initiatives (Brady, 2002). The partnership focused on shared research, in which teacher inquiry provided teachers with a critical orientation to their practice, and demonstrated that they could conduct research in their schools that led to meaningful change and enhanced teacher professionalism. Schools work with university staff to support school - based action research.

On the other hand, there are some challenges in partnership between pedagogy universities and schoos in practicum. For instant, Schools seemed to be relegated to playing a subordinate role which involves providing a classroom and a mentor, thus merely offering practice fields where student teachers can try out their practices, as recommended or even demanded by the colleges (Clark, 1999; Keogh et al, 2006; Clarke et al, 2014; Gravett et al, 2014; Foerste et al, 2017; Magudu \& Gumbo, 2018) 
Student teachers' accounts of their school-based experiences suggest that teacher-mentors are not always successful in creating conditions for effective student teacher learning (Hobson, 2002). Duda (2011) tried his best to research the partnership in teacher training through over the European countries and pointed out that there are some dificulties in creating partnerships between school and pedagogy institutions. They are "poor organisation of teacher practices; insufficient duration of pedagogical practices in schools; lack of monitoring; lack of mentoring staff in schools; gap between theory and practice; schools not perceived as places for teacher training; schools considered mainly as 'venue providers' for students' teaching practices; low quality teaching practice; unclear, situational and uncoordinated forms of promotion of such partnerships; weak links between universities and schools, basic training and advanced training of teacher".

In reality, many researchers showed that the coordination between pedagogical universities and high schools in teacher training still had many problems. Many school teachers are not enthusiastic, creating conditions for students; Many members of the management board of the practical schools also expressed fatigue, laziness and perfunctory towards organizing practicum in training activities for students. Moreover, the guidance of pedagogical skills for students has not been identified by local high schools as one of the main tasks. The theoretical knowledge about educational science of the board members is still low, affecting the mastery of the objectives, contents and methods of organizing the operation of training modules and sub-modules practicum. Therefore, the implementation, organization, management, training activities and evaluation of training results for students are not effective. The level of instructors of the schools is uneven, there are people with good professional qualifications, strong pedagogical experience, initiative and creativity in guiding students. (Chu, 2017; Duda, 2011).

\subsection{Methods of Partnership Between Pedagogy Universities and Schoos in Praticum to Train Student Teacher}

The combination of student teachers, clinical instructors, university faculties, and shared professional development activities greatly reduces teacher isolation and increases morale as they have regular opportunities for planning, brainstorming, and sharing with other professionals (Holen et al, 2014). There have also been a variety of more specific partnership initiatives (Brady, 2002). The partnership focused on shared research, in which teacher inquiry provided teachers with a critical orientation to their practice, and demonstrated that they could conduct research in their schools that led to meaningful change and enhanced teacher professionalism. Under Smith and Karl (2016) approach, universities assign students to schools for practice teaching, and there is a clear division of responsibilities between the school and the university. He researched three models of partnership between schools and teacher education university. They are: practice schools model, partner schools model, university schools model.

Duda in 2011 catergorised the forms of partnerships as follows: "an agreement on collaboration signed between a school and university to co-operate in a specific sphere, e.g. language education (Armenia); 'school-university' clusters, within which school teachers are involved in the development and implementation of educational programmes at all stages of their planning and implementation (Armenia); contracts of co-operation to carry out the traditional format of 'pedpraktiki' (pedagogical practices) (Armenia, Azerbaijan, Belarus); contracts of co-operation between TE institutions and schools that want to become a 'centre of teacher training' providing teaching practice; such schools receive bonuses during accreditation and teachers are strongly supported in their pedagogical practice (Moldova)."

Handscomb et al (2014) mentioned that externally, there are three types of relationships with schools, ranging from "a) an information diffusion oriented relationship, b) a supportive facilitating relationship, and c) a closer cooperative relationship which is made up of direct links with, first teachers, and later with students, with the school acting as a gatekeeper. The internal relationships with academics tend to be informal and flexible and the level of their engagement ranges from a) attempting to engage, b) developing involvement and c) close reciprocal interaction". They cited the result of Day et al. to argue that "whilst the WP team provides a leadership and brokerage role in matching internal expertise with external needs, this role with schools and pupils may be most accurately described as one of development and diffusion" (Handscomb, p.25).

Partnership models may vary based on the nature of the contract or partnership agreement, financial arrangements, number, and type of partner institutions involved, focus of the partnership, and the geographical context of the partnership (Fekadu \&Melese, 2012). There are two kinds of model consisting Collaborative partnerships and directed partnership. "Academic debates refer to partnership as a strategy that is used by schools in the "resource" state during the process of elementary teacher education. In this type of relationship, the educational institution, i.e., the university, has all the decision-making power in terms of what to do and how to do it. The school is considered to be a means for learning that sets the practical aspects required in the elementary education curricula. The elementary school teachers 
are considered to be a type of consultants who perform tasks in a given project designed and conducted by academia without a clearly defined benefit of extended education." (Foerste et al, 2017).

Gauthier (2017) considered that the partnership with the school district starts at the college level. The college or the university also has the task of working with its professors on revamping their courses. This would include sharing the information learned during the monthly meetings with the professors and guiding them on the necessary changes to the coursework. This process would evolve on a monthly basis as new learnings come to light. Colleges and universities will collaborate with the school district to align the teacher preparation program with the standards they have created. The school district will attend and contribute to the monthly meetings with local colleges and universities. All parties will work together to make sure the standards created align with current practices. All along the way the district will inform the college team of what is working and what is missing when new teachers come into the classroom. School administrators see firsthand the impact that teachers have on students. They can provide crucial feedback on which teachers would prove to be strong mentors. This mentorship will start early on in the educational career of the college student. Classroom teachers will also be active participants in this process. They will host the teacher candidates in their classrooms.

Foerste (2017)) found an innovation in the partnership between pedagogy universities and schools, the author called as "Separatist partnership". In the model, the government has presented its alternative, the so-called separatist partnership (from the English term "separatist"). This practice is relatively recent in elementary teacher education and is a direct result of the administration seeking more suitable alternatives to implement the purposes of public reforms. According to the government, this official alternative partnership ensures a necessary integration among the universities, schools and government, from assumptions that have not yet been made public (pp.1278-1279)

\subsection{Components Partnerships in Teacher Education Relating to Practicum}

The school might get involved in the initial education of new teachers. Staffs within the school might get opportunity for in-service training, increase school's capacity for innovation and knowledge development through support from teacher educators and through student- teachers' development and research activities, the partnership creates a bridge for feedback of the outcomes of education research into the reality of the professional within schools. The function of the partnership contributes in "(1) supporting initial teacher education, (2) enhancing continuing professional development and (3) creating research communities aimed at knowledge building often in form of consultancy" (Fekadu \&Melese, 2012; Halasz, 2016).

El-Amin \& Hammond (2000) identified some common components of evolving partnerships relating to practicum that describe what they can do: "Enhance pre-service education. Future teachers are prepared in programs that link college/university instruction and practical experiences in schools. Promote and conduct inquiry in teaching and learning. Partners view themselves as lifelong learners and continuously investigate the factors that contribute to successful teaching and learning. Provide a model school or exemplary setting. Partners seek to create an optimal learning environment for all participants. Promote positive outcomes for students in PreK-12. Partners seek to optimize outcomes for students as well as educators. Change university teacher preparation programs. Teacher preparation programs benefit from grounded experience with schools, which help make university programs relevant. Integrate theory, research, practice and assessment. All parties benefit from a continuously self-informing cycle of theory -research -practice - assessment."

According to Cain (2009), there are "four ways in which mentors might engage with this literature: (1) generalisations, generated by research, can inform practice directly; (2) mentoring can be better understood by reference to theoretical frameworks derived from the literature; (3) in-depth case studies can provide vicarious experiences of mentoring; and (4) mentors might use research methods to inquire into their own practice".

Hennissen et al (2011) argured the essential role of both university and school staff is also highlighted. These components of relationship forcus on: Guiding Pedagogical Principles; Growing University-School Partnerships; Representations of Partnership; and Growth Model provide a scaffold for initiating, growing and sustaining partnerships that maximise the benefits for all.

The analysis of Clarke et al research in 2014 draws of participation to generate 11 different ways that cooperating teachers participate in teacher education: as Providers of Feedback, Gatekeepers of the Profession, Modelers of Practice, Supporters of Reflection, Gleaners of Knowledge, Purveyors of Context, Conveners of Relation, Agents of Socialization, Advocates of the Practical, Abiders of Change, and Teachers of Children.

Greany \& Brown in 2015 pointed out that partnerships are more successful, the review identifies the following factors: "Power and control: all voices to be heard. Successful partnerships reject a hierarchical approach in which the 
university dominates and practitioner knowledge is devalued. Mind the gap - cultural differences. Successful partnerships often appear to succeed by creating a 'third space' which is separate from the culture of either institution and allows for more creative ways of working. The importance of leadership. Partnerships and networks are not naturally self-organising. Strategic relevance and fit. Partnerships work well when there is joined-up coherence and strategic fit. Material resources: making it happen. Partnerships pose a challenge and have transaction costs - the time, energy and resources necessary to keep the partnership alive and well. Therefore funding is a crucial contributor to partnership success, but partnerships also need to develop strategies to persist in austere times."

Duda (2011) researched relationships between teacher education institutions and schools in Eruopian countries to identify in the following areas: " student classroom practices; Instruction/ mentoring; organising induction period; development of training programmes or solutions to specific problems; re-training of teachers; joint development of lists of general, cognitive, professional and creative competencies necessary for success in the educational market; professional teacher development in higher education institutions (every five years); development of standards, curricula/study programmes, textbooks and teaching instruments for schools, development of NQF; individual counselling to novice teachers at their request contests of students' scientific works carried out in close cooperation with secondary schools - centres of students' practice; olympiads (competitions) in various subjects organised by pedagogical universities, and scientific conferences, seminars, 'school of young teacher' programme; system of block teaching practice at secondary schools parallel with studying at university; joint realisation of international/national projects, programmes, seminars".

Such partnership necessitates an integrative programme design to counteract the schism between the 'world of theory' and the 'world of practice' and draw optimally on collaboration between teacher educators and teachers who supervise students in schools to achieve this (Gauthier, 2017)

Since student teachers begin their semester with extended and progressively demanding experience working in school settings, teachers receive real assistance in teaching and managing their classroom when they accept responsibilities as a cooperating teacher (Holen et al, 2014). The relationship between pedagogy universities and schools significantly reduces the isolation of teachers. Teachers develop subject matter through regular planning, brainstorming and sharing with other professionals. The role of the universities includes: sharing research, setting requirements for instructors and improving the professionalism of teachers. Collaboration between schools and universities is described in the role of developing criteria, processes and providing professional experience for students. The role of teachers in the school focuses on: supervision and mentoring; teaching initiatives; research; Professional development; shared planning; and enrich and support the school.

My (2014) stated that, the relationship between pedagogical institution and high school is a core relationship in solving many important issues of general education development and the operation of teacher training institutions. The connection between the pedagogical institution and the high school is an essential requirement in teacher training. This link is in many areas but mainly in the field of pedagogical practicum. In the association, there are some limitations that come from the pedagogical institution and the high school, the lack of development investment for the partners participating in the training and the lack of legal obligations between the two sides. The relationship between the pedagogical institution and the school should be considered as a guideline for pedagogical practicum; Develop a mechanism of community co-operation between universities and high schools in the model of "creation base product" with "consumer products"; Need to build a network of practicum schools; At the same time, it is necessary to sign long-term contracts and close coordination between the pedagogical product and the high school. This relationship represents the interests of both sides towards the common goal for the cause of growing people. The pedagogical product is a training facility for teachers and schools, which is a basis for practicum and is a teacher use unit trained by pedagogical institutions. Pedagogical universities and schools have many binding relationships.

The review of the literature identified that research on partnership of pedagogy universities and schools relating to practicum is not as plentiful as research on partnership general. The problem $\mathrm{m}$ is that these studies are less information and very few studies in this context of Vietnam. This study focuses the lens on partnerships between pedagogy universities and schools relating to Practicum to train pre-service teacher education.

The digram below showed the literature of partnership between schools and pedagogy universities in teacher education 


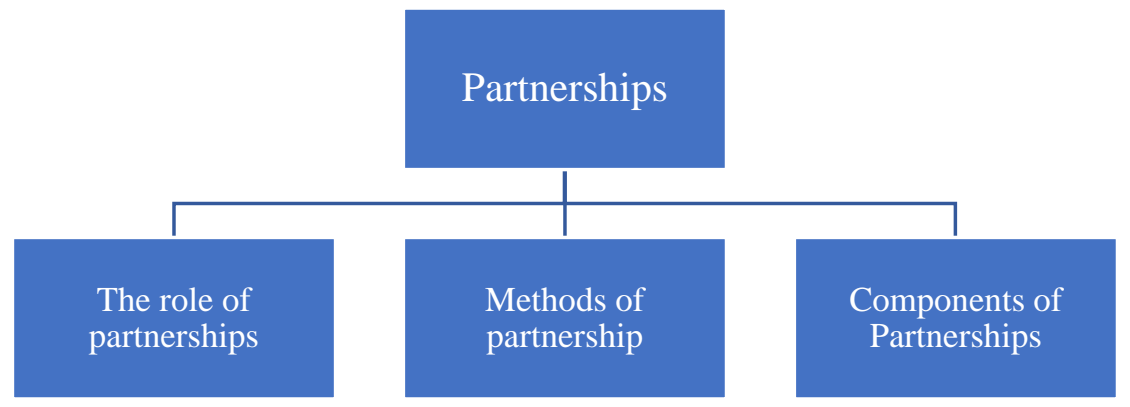

\section{Methodology}

\subsection{Data Sources}

This study used a mixed - methods design to gather quantitative and qualitative data simultaneously (Creswell, 2012). The questionnaires used open - ended and closed-ended questions with 5 point Likert scales. By answering the questions, the extent of partnership between schools and pedagogy universities in teacher education can be revealed and recognized.

In this study, the characteristics of partnership between schools and teacher education universities in teacher education were used as a theoretical framework to set up specific themes and questions for the questionnaires. Accordingly, the questionnaires focus on determining awareness and attitudes implemented by teachers, lecturers and students in practicum process. The questionnaires were discussed intensively several times with other researchers as regarding their words before they were used in practice. In this study, the data come from three main sources:

- Teacher questionnaires,

- Student questionnaires,

- Lecturers questionnaires

The questionnaires applied similar content for the questions, with an emphasis on specific, visible and measurable manifestations of the partnership between schools and teacher education universities in teacher education and attitudes about the activities of school and teacher education universities. Specifically, the questions were about:

- The importance and level of the coordinating contents between the school and the pedagogy university in practicum to training teachers;

- The level of implementation and awareness between the school and the teacher education university in practicum to training teachers;

\subsection{Participants}

Participants in this research consist of 243. They are 81 student teachers (STs) enrolled in the Bachelor of Education with a specialisation in general education; 85 teachers and 77 lecturers. The proportions among the survey subjects are shown in the Table below

Table 1. Information about sample of the survey

\begin{tabular}{llll}
\hline Participant & Teachers & Lecturers & Students \\
\hline Number & 85 & 77 & 81 \\
& & & \\
Proportion (\%) & 35 & 32 & 33
\end{tabular}

The participants' ages ranged from 18 to more than 45 years old. The purposeful sample participants were also categorized into foủr groups; those with between 35 - 45 and 23-35 years old were labeled as majority accounting for $36 \%$ and $30 \%$. They are experienced teachers, lecturers and relevant to students' internships at secondary schools. They also play a vital role in being responsibility for practicum either in pedagogy universities or schools. This ratio helps survey results be more reliability. 


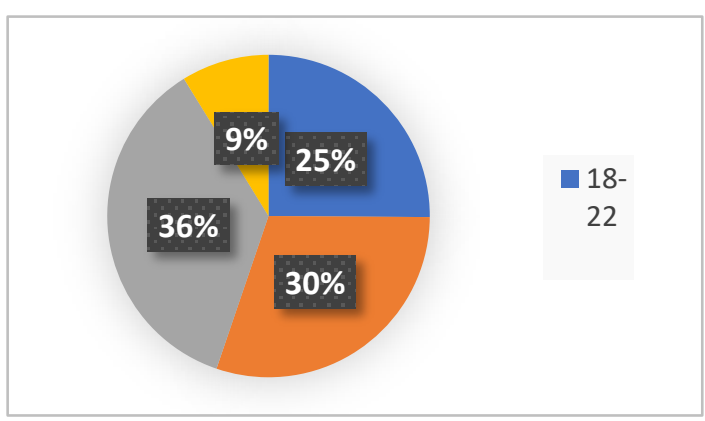

Figure 1. Age of the surveyed participants

The gender of the participants is shown in the Figure 2.

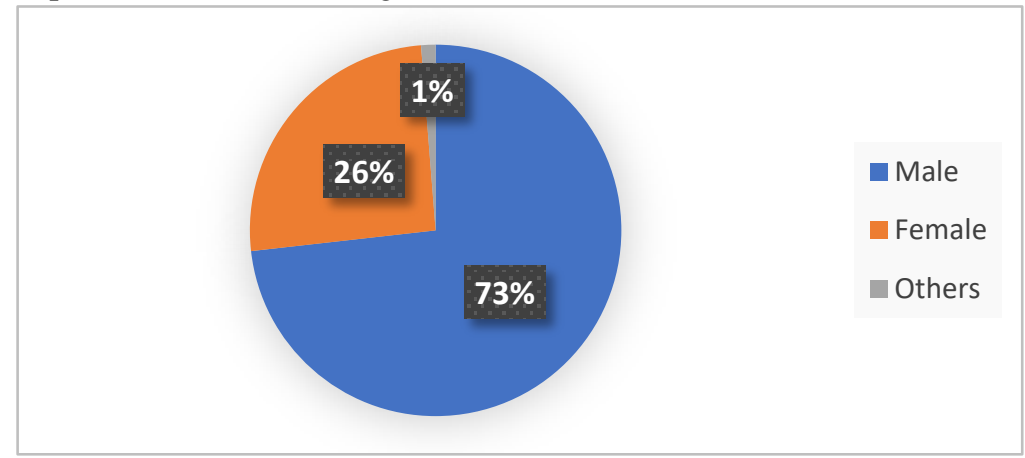

Figure 2. Gender of surveyed participants

The graph shows that the majority of the participants is female (73\%), otherwide, male account for $26 \%$ and non-gender respondents account for only $1 \%$ (3 participants). It is is easy to explain because the paticipants belong to pedagogical aspect. This proves that the sampling is suitable with the industry-specific characteristics, which is the basis for proposing solutions that are highly feasible.

The chart below described that the majority of the participants are educational sciences and social sciences, the proportion of these sectors accounts for $42 \%$ and 39\% respectively, while the people are in the natural science accounting for $19 \%$. This supported the cause of the situation, thereby proposing appropriate solutions.

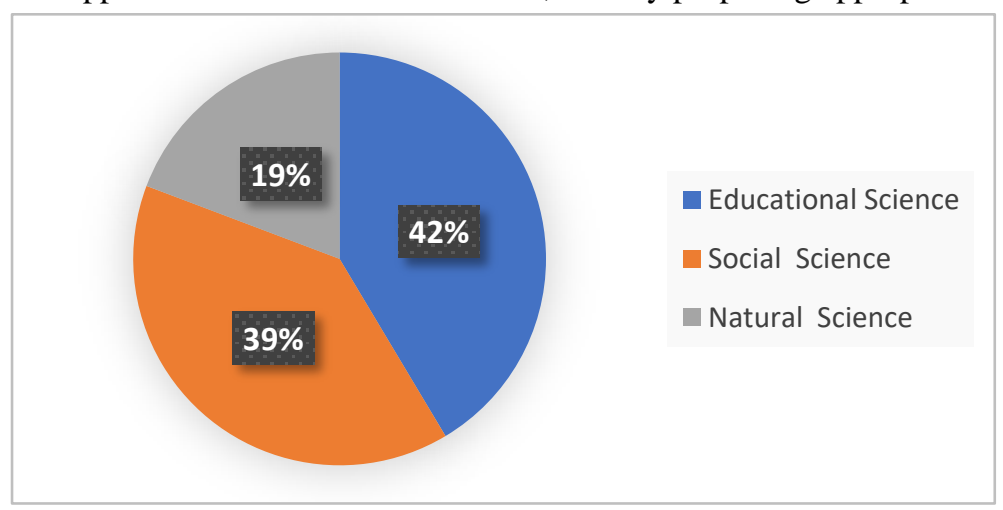

Figure 3. The training sector of the surveyed participants

\subsection{Collection and Analysis}

The questionnaire surveys were implemented in two phases. The first was a pilot phase and the second was the official phase. The aim of the pilot phase was to check whether the designed questionnaires were effective or not in obtaining the most complete and accurate information from teachers and students. The analysis of the data from the pilot phase showed that some questions were not expressed appropriately enough to make the teachers, lecturers and students provide information in a detached and honest manner. After that, the questionnaires were adjusted and reworded to encourage the teachers, lecturers and students to provide accurate, unbiased and complete information regarding the research issue. In both of the survey phases, instructions were given to the teachers, lecturers and students in order to help them understand the questions and guide them in how to work on the questionnaires. The teachers, lectures and the 
students were encouraged to be free, honest and detached in order to provide accurate answers to the questions in the questionnaires.

Quantitative data was analysed using SPSS 20.0 . Descriptive statistics employed include frequency counts and percentage distribution. The results from the SPSS assessment were read carefully by the author, to obtain a general sense of the information and get an opportunity to reflect on its overall meaning in terms of the partnership between schools and teacher education universities in teacher education. After that, they were coded by writing words representing categories of partnership between schools and teacher education universities in teacher education activities and attitudes, and later divided into themes for the findings that emerged from the evidence.

Accordingly, coherent interpretations of the themes of the findings were made. The data analysis involved several steps. Firstly, a detailed descriptive analysis of the collected data was carried out by the author. The analysis indicated means and ranges of scores for the variables. After that, the descriptive analysis was presented and intensively discussed several times with other researchers from the same field as the author. In this way, the data were validated and reliable findings were produced. This also led to a discussion about the implications of promoting the partnership between schools and teacher education universities in teacher education. Qualitative data were analysed using thematic analysis (Braun \& Clarke, 2006).

\subsection{The Reliability and Validity of the Scale}

To conduct an analysis of the correlation of each item for the entire scale, the KMO coefficient was calculated to ensure the reliability. KMO index and Sig value of $<0.005$ show that the scale is eligible for factor analysis.

Table 2. Correlation of points between sub-scales / scales

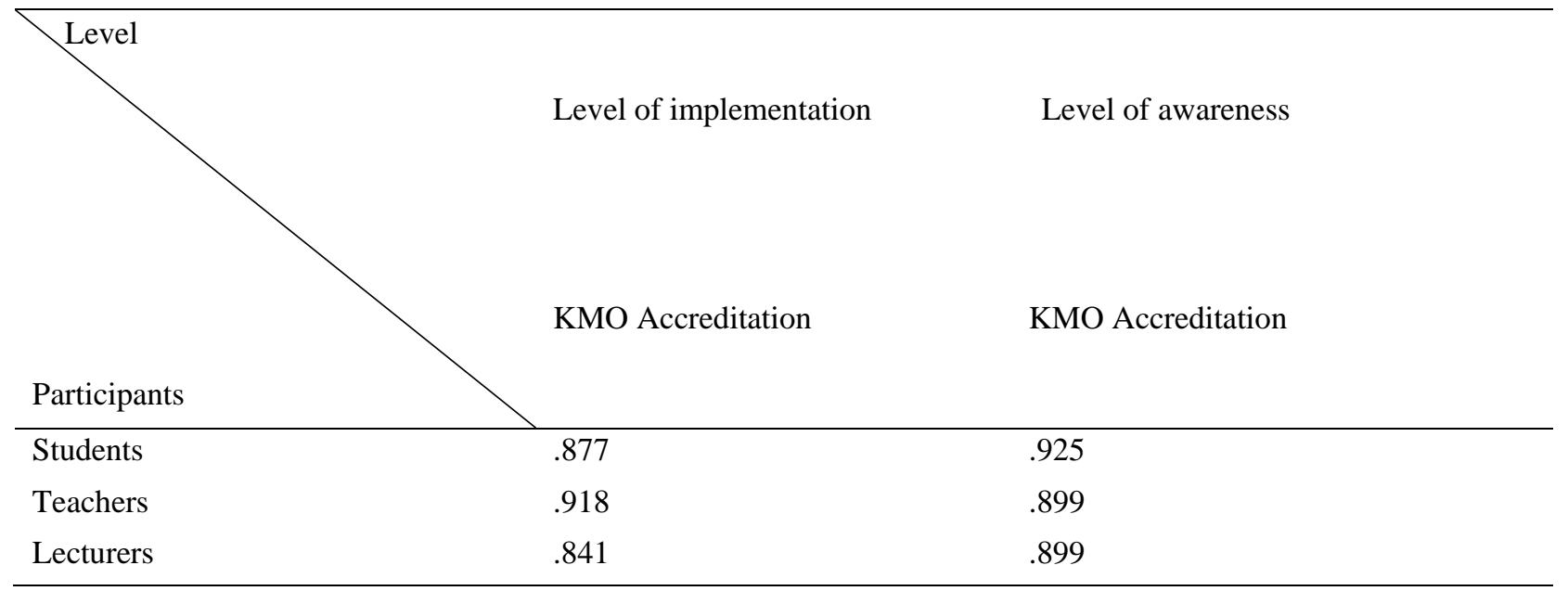

To assess the reliability of the toolkit in this study, the research used the method of assessing the correlation between items in the same measuring domain (internal consistency methods), using Cronbach's Alpha correlation model (Cronbach's Coefficient Alpha). This model evaluates the reliability of a measurement based on the calculation of the variance of each item in each scale, the entire measurement, and the correlation of the point of each item with the points of the remaining items on each scale and of the whole measurement. The reliability of each sub-scale is considered low if the alpha coefficient is $<0.40$. The reliability of the whole scale is considered low if the alpha coefficient is $<0.60$. The results of factor analysis and Cronchbach Alpha reliability coefficient are from .929 to. 973 . They show a believable measurement scale.

Table 3. The reliability of the scale

\begin{tabular}{|c|c|c|c|c|c|c|}
\hline \multirow[b]{2}{*}{ Contents } & \multicolumn{2}{|c|}{ Students } & \multicolumn{2}{|l|}{ Teachers } & \multicolumn{2}{|c|}{ Lecturers } \\
\hline & $\mathrm{N}$ & $\begin{array}{l}\text { Cronbah } \\
\text { Alpha }\end{array}$ & $\mathrm{N}$ & $\begin{array}{l}\text { Cronbah } \\
\text { Alpha }\end{array}$ & $\mathrm{N}$ & $\begin{array}{l}\text { Cronbah } \\
\text { Alpha }\end{array}$ \\
\hline $\begin{array}{l}\text { Degree of } \\
\text { implementation about } \\
\text { the partnernship } \\
\text { between schools and }\end{array}$ & 81 & .958 & 85 & .969 & 77 & .929 \\
\hline
\end{tabular}


pedagogical

universities in teacher

training through

practicum

Degree of awareness

81

.971

85

.973

77

.968

between schools and

pedagogical

universities in teacher

training through

practicum

\section{Results}

In order to understand the awareness of the survey subjects about the importance of the current relationship between high schools and pedagogical universities in teacher training through pedagogical practice, we use question in the survey questionaries. The results are statistically described in Figure.4

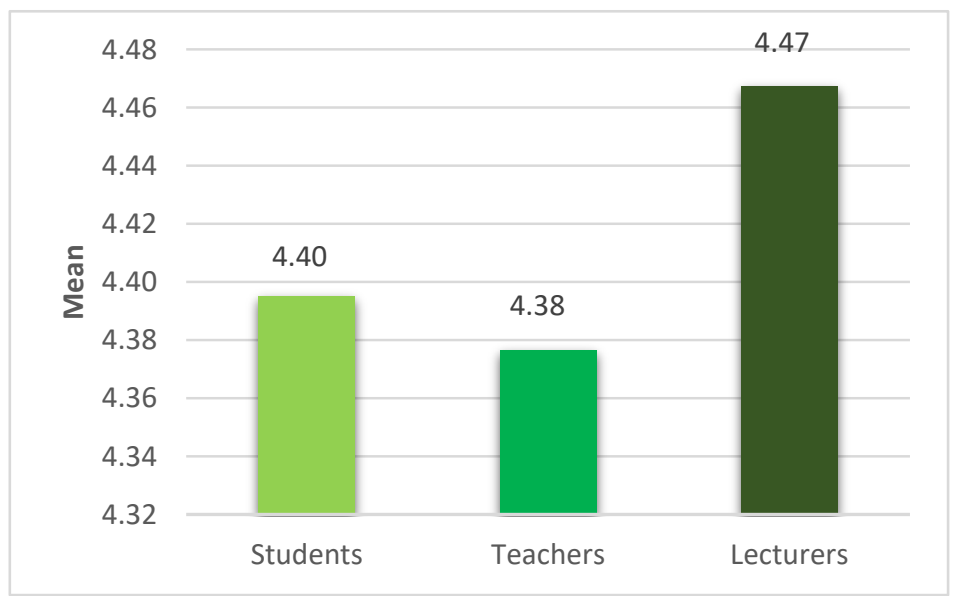

Figure 4. The awareness of the tightness about the partnernship between schools and pedagogical universities in teacher training through practicum

The Figure 4 described that there is little difference in the awareness of the participants when assessing the importance of the current partnership between schools and pedagogical universities through practicum. The average value of the target groups in descending order are lecturers $($ Mean $=4.47)$, students $($ Mean $=4.40)$, teachers $($ Mean $=4.38)$. In particular, the highest of mean is ranked by lecturer.

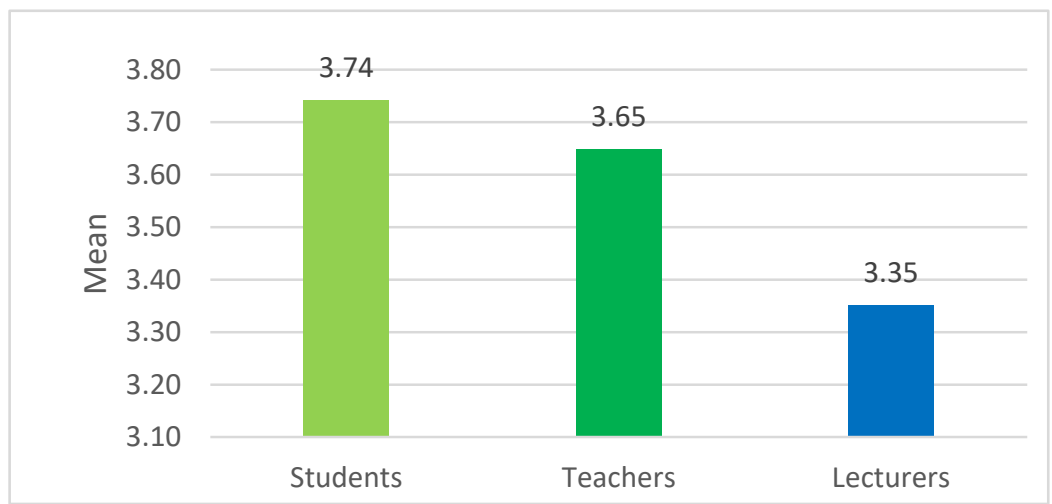

Figure 5. The importance of the partnership between schools and pedagogical universities in teacher training through practicum

The chart 5 show that it is possible to see the change in the order of evaluation among the difference participant groups. Accordingly, the participant group assesses the highest partnership between schools and pedagogical universities in 
teacher training through practicum is students (Mean $=3.74$ ), followed by teachers (Mean $=3.65$ ). The lecturers mentioned with the lowest Mean=3.35.

Table 4. Summary of the tightness and importance in partnership between schools and pedagogical universities through practicum to train teacher

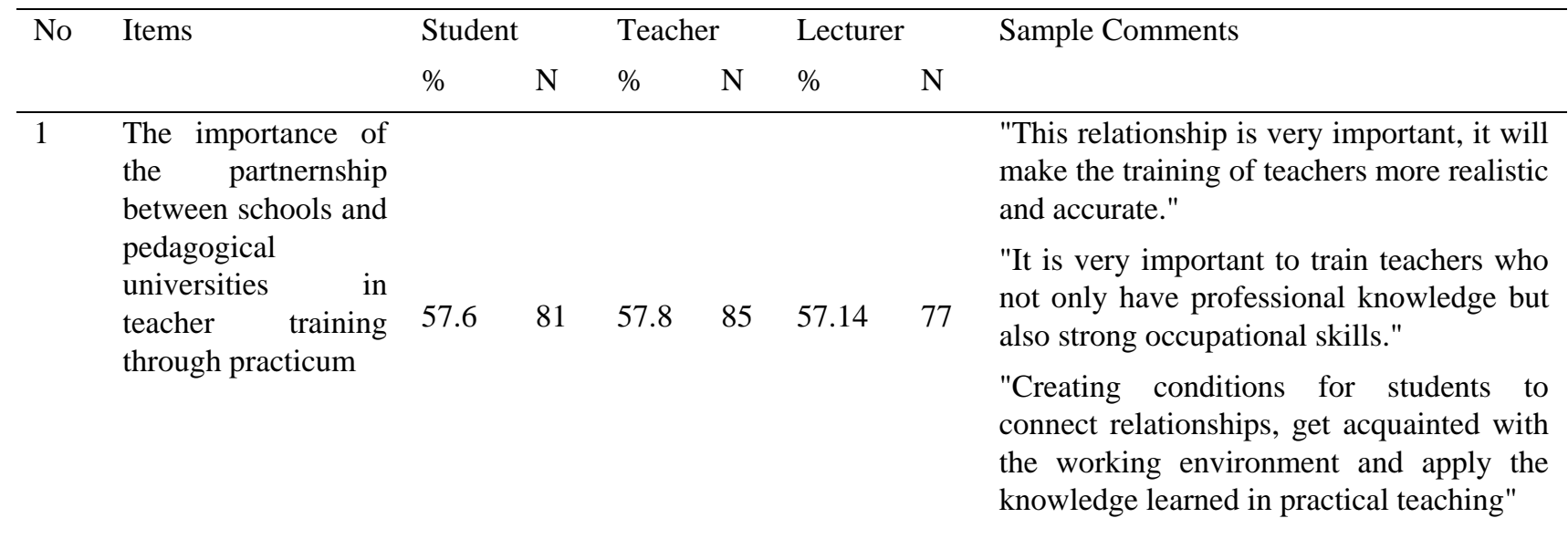

2 The tightness

\begin{tabular}{|c|c|c|c|c|c|c|}
\hline $\begin{array}{l}\text { pedagogical } \\
\text { universities in } \\
\text { teacher training } \\
\text { through practicum }\end{array}$ & 23.5 & 81 & 21.0 & 85 & 53.24 & 77 \\
\hline
\end{tabular}

"There should be a better relationship to evaluate and help students with the best quality" "There is a close relationship with each other in each stage" "Peadagogy Universities and schools have a close relationship in teacher training because of its nature"

Table 4 represents the responses of participants with regard to their awareness about how tightly and important relationship between pedagogy universitites and schools. Similar percentages of teachers (57.8\%), lecturers (57.14\%) and students $(57.6 \%)$ agreed that relationship between pedagogy universities and schools is important. There was a difference between students, teachers $(23.5 \%, 21.0)$ and lectures $(53.24 \%)$ in their awareness of issue.

Table 5. Student assessment of the partnership between schools and pedagogical universities in teacher training through practicum

\begin{tabular}{|c|c|c|c|c|c|c|c|c|}
\hline \multirow[t]{2}{*}{ No. } & \multirow[t]{2}{*}{ Items } & \multirow{2}{*}{$\begin{array}{l}\text { Number } \\
\text { of } \\
\text { Student }\end{array}$} & \multicolumn{2}{|c|}{$\begin{array}{l}\text { Level } \\
\text { implementation }\end{array}$} & \multirow[t]{2}{*}{ Rank } & \multicolumn{2}{|c|}{$\begin{array}{ll}\text { Level of } \\
\text { importance }\end{array}$} & \multirow[t]{2}{*}{ Rank } \\
\hline & & & Mean & $\begin{array}{l}\text { Std. } \\
\text { Deviation }\end{array}$ & & Mean & $\begin{array}{l}\text { Std. } \\
\text { Deviation }\end{array}$ & \\
\hline 1 & 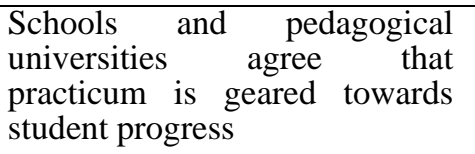 & 81 & 3.6790 & .78783 & 6 & 3.9012 & .76819 & 6 \\
\hline 2 & $\begin{array}{l}\text { Schools and pedagogical } \\
\text { universities consider practicum } \\
\text { as a process of connecting } \\
\text { theories with practices. }\end{array}$ & 81 & 3.7901 & .81725 & 3 & 3.8642 & .75421 & 12 \\
\hline 3 & $\begin{array}{l}\text { Schools and pedagogical } \\
\text { universities have made the best } \\
\text { efforts according to regulations } \\
\text { to train teachers }\end{array}$ & 81 & 3.7654 & .82571 & 4 & 3.8889 & .80623 & 9 \\
\hline 4 & $\begin{array}{l}\text { Improve the curriculum and } \\
\text { effectiveness of practicum }\end{array}$ & 81 & 3.5679 & .77360 & 12 & 3.9136 & .88314 & 5 \\
\hline
\end{tabular}


5 Schools and pedagogical universities agreed on the beginning and finishing timetable of practicum

81

Schools and pedagogical universities exchanged agreement on the number of students attending the practicum

7 Exchanging, consulting and 81 adjusting the content of practicum, assessment of practicum

8 Lecturers and teachers participate in guiding students

9 Schools and pedagogical universities often contact to discuss the situation of students

10 Discussing to unify the mechanism for the activities of stakeholders in practicum

11 Pedagogical universities preside over the practicum curriculum development , plans and contents

12 The schools organize practicum according to the schedule available from the pedagogical universities

13

The school determines the number of students based on the practical situation

14 Teachers and lecturers give 81 opinions about students' result

15 The schools determine the 81 student's result

16 The pedagogical universities collaborate with the schools to decide the pedagogical practicum results

17 Organize exchange of students' practicum

$3.5802 \quad .89253$

$3.6420 \quad .91253$

effectiveness of practicum

19 Lecturers regularly visit schools
10

$3.8765 \quad .84236$

8

1

$3.9877 \quad 79834$

2

15

$3.8148 \quad .88192$

$7 \mathrm{a}$

3

$3.9753 \quad .74120$

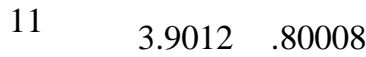

7

16

$3.9012 \quad .81555$

15

13

$3.8519 \quad .79232$

$7 b$

14

$3.8395 \quad 78193$

13

18

$3.7531 \quad .87365$

17

20

$3.6296 \quad 85797$

14

$3.9136 \quad 83961$

4

19

$3.7284 \quad .89460$

5

$3.8889 \quad 1.02470$

10

11

2

$3.9877 \quad .87312$

19

$\begin{array}{llll}3.2963 & 1.01790 & 3.7531 & .76699\end{array}$ 
20 The schools often contact to discuss the situation of the students
81

18
16

\section{$\begin{array}{llll}3.3333 & .90830 & 3.7654 & .82571\end{array}$}

On the student's side, most of the content reached a value from 3.4 to 3.8. This demonstrated the regularity and continuity in maintaining the relationship between the Pedagogical University and the high school in pedagogical practice to train teachers.

The highest scoring criterions are: "Schools and pedagogical universities agreed on the beginning and finishing timetable of practicum" with Mean $=3.8148$, Schools and pedagogical universities exchanged agreement on the number of student attending the practicum" with Mean $=3.8025$; and Schools and pedagogical universities consider practicum as a process of connecting theories with practices with Mean $=3.7901$.

There are 2 criterions being evaluated at medium levels. They are: "The schools often contact to discuss the situation of the students" with mean $=3.3333$ and "Lecturers regularly visit schools" with mean =3.2963.

Considering the importance of this relationship also according to the above criteria, the average value ranges from 3.6 to nearly 4.0. Most of the students have affirmed that the relationship between Pedagogical University and school is very important in training teacher.

The highest average value is determined in the criterions: "Schools and pedagogical universities agreed on the beginning and finishing timetable of practicum" and "Confernce to improve the effectiveness of practicum" (Mean =3.9877). There is some items that is less appreciated such as "The schools organize practicum according to the schedule available from the pedagogical univerisites" with Mean = 3.7531; "The schools determine the student's reult" with Mean $=3.7284$; The lowest is The school determines the number of students based on the practical situation" with Mean $=3,6296$.

Table 6. Lecturer assessment of the partnernship between schools and pedagogical universities in teacher training through practicum

\begin{tabular}{|c|c|c|c|c|c|c|c|c|}
\hline \multirow[t]{2}{*}{ N0 } & \multirow[t]{2}{*}{ Items } & \multirow{2}{*}{$\begin{array}{l}\text { Number } \\
\text { of } \\
\text { Lecture }\end{array}$} & \multicolumn{2}{|c|}{$\begin{array}{l}\text { Level } \\
\text { implementation }\end{array}$} & \multirow[t]{2}{*}{ Rank } & \multicolumn{2}{|c|}{ Level of importance } & \multirow[t]{2}{*}{ Rank } \\
\hline & & & Mean & $\begin{array}{l}\text { Std. } \\
\text { Deviation }\end{array}$ & & Mean & $\begin{array}{l}\text { Std. } \\
\text { Deviation }\end{array}$ & \\
\hline 1 & $\begin{array}{l}\text { Schools and pedagogical } \\
\text { universities agree that } \\
\text { practicum is geared towards } \\
\text { student progress }\end{array}$ & 77 & 3.3896 & .82965 & & 3.6494 & .91430 & \\
\hline & & & & & 12 & & & 7 \\
\hline 2 & $\begin{array}{l}\text { Schools and pedagogical } \\
\text { universities consider } \\
\text { practicum as a process of } \\
\text { connecting theories with } \\
\text { practices. }\end{array}$ & 77 & 3.6364 & .64704 & & 3.8961 & .88235 & \\
\hline & & & & & 3 & & & 1 \\
\hline 3 & $\begin{array}{l}\text { Schools and pedagogical } \\
\text { universities have made the } \\
\text { best efforts according to } \\
\text { regulations to train teachers }\end{array}$ & 77 & 3.4675 & .77093 & & 3.7792 & .94065 & \\
\hline & & & & & 9 & & & 3 \\
\hline 4 & $\begin{array}{l}\text { Improve the curriculum and } \\
\text { effectiveness of practicum }\end{array}$ & 77 & 3.4026 & .69320 & & 3.8312 & .86454 & \\
\hline 5 & $\begin{array}{l}\text { Schools and pedagogical } \\
\text { universities agreed on the } \\
\text { beginning and finishing } \\
\text { timetable of practicum }\end{array}$ & 77 & 3.7662 & .91617 & 11 & 3.6883 & .84697 & 2 \\
\hline & & & & & 2 & & & 4 \\
\hline 6 & $\begin{array}{l}\text { Schools and pedagogical } \\
\text { universities exchanged } \\
\text { agreement on the number of } \\
\text { students attending the } \\
\text { practicum }\end{array}$ & 77 & 3.5844 & .74957 & 4 & 3.6104 & .84536 & 9 \\
\hline
\end{tabular}


7 Exchanging, consulting and 77 adjusting the content of practicum, assessment of practicum

$\begin{array}{llll}3.2468 & .87593 & 3.5195 & 1.10751\end{array}$

8 Lecturers and teachers 77 participate in guiding students

$9 \begin{aligned} & \text { Schools and pedagogical } \\ & \text { universities often contact to }\end{aligned}$ discuss the situation of students

77

Discussing to unify the mechanism for the activities of stakeholders in practicum

77

Pedagogical universities preside over the practicum curriculum development , plans and contents

77

The schools organize practicum according to the schedule available from the pedagogical universities

77

$\begin{array}{llll}3.8312 & .65700 & 3.6883 & .89236\end{array}$

17

$3.3506 \quad .87006$

$3.5974 \quad .92138$

14

$3.4156 \quad .78389$

3.5844

.95077

10

$3.3896 \quad .84536$

3.5325

.94011

12

1

4

$\begin{array}{llll}3.5584 & .81907 & 3.4026 & .94951\end{array}$

5

16

13 The school determines the number of students based on the practical situation

$3.1948 \quad .96025$

$3.2597 \quad 1.03113$

18

14 Teachers and lecturers give opinions about students' result

$3.2727 \quad .94083$

$3.5325 \quad 1.00766$

15

12

$3.5455 \quad .91112$

$3.4026 \quad .96327$

student's result

77

The pedagogical universities collaborate with the schools to decide the pedagogical practicum results

77

$\begin{array}{llll}3.1429 & 1.04773 & 3.5065 & 1.05909\end{array}$

Organize exchange of 77

students' practicum

3.5584

.83498

19

15

$3.6364 \quad .93061$

5

8

$3.5455 \quad .77026$

3.6623

.95436

effectiveness of practicum

$3.2597 \quad .78477$

7

6

16

3.3766

.93244

19

20 The schools often contact to 77 discuss the situation of the students

$2.9221 \quad 1.09744$

3.3896

1.00205

16

20

18

The results of the table above show that there are 20 criterions to evaluate the level of participant between pedagogical universities and schools. In particular, there are 17 assessment contents with Mean higher than 3.2 being rated as good with the implementation and there are 3 criterions being evaluated Good.

Ranking number 1 is the content "Pedagogical universities presides over the practicum curriculum development, plans and contents" with mean $=3.8312$. 
Followed by "Schools and pedagogical universities agreed on the beginning and finishing timetable of practicum with mean $=3.6364$

The contents that are assessed not performing well including "The schools often contact to discuss the situation of the students" (Mean = 2.9221); "The pedagogical unversoties collaborate with the schools to decide the pedagogical practicum results" (Mean=3.1429). On the importance of this relationship side, the items "Schools and pedagogical universities consider practicum as a process of connecting theories with practices" (Mean = 3.8961 And "Improve the curriculum and effectiveness of practicum" (Mean = 3.8312) reach the highest. The contents that are assessed the lowest consisting of "The school determines the number of students based on the practical situation" (mean =3.2597); "Lecturers regularly visit schools" ( mean $=3.3766$ )

Table 7. Teacher assessment of the partnernship between schools and pedagogical universities in teacher training through practicum

\begin{tabular}{lllllll}
\hline N0 & Items & Number & Level & of & Rank & Level of importance \\
Rank
\end{tabular}

of Teacher implementation

Mean Std. Mean Std.

Deviation Deviation

1 Schools and pedagogical 85 universities agree that practicum is geared towards student progress

$3.3882 \quad .88767$

$3.8000 \quad .88372$

12

6

2 Schools and pedagogical 85 universities consider practicum as a process of connecting theories with practices.

$\begin{array}{llll}3.6000 & .80475 & 3.8118 & .82367\end{array}$

1

4

3 Schools and pedagogical universities have made the best efforts according to regulations to train teachers

85
$3.4824 \quad .88118$
$3.7529 \quad .78537$

8

12

4 Improve the curriculum and 85 effectiveness of practicum

$3.4118 \quad .86319$

$3.7647 \quad .82588$

10

9

5 Schools and pedagogical universities agreed on the beginning and finishing timetable of practicum

85

$\begin{array}{llll}3.6000 & .92839 & 3.7529 & .78537\end{array}$

1

12

6 Schools and pedagogical universities exchanged agreement on the number of students attending the practicum

$3.5882 \quad .92959$

$3.6588 \quad .80995$

4

15

$\begin{array}{llll}3.4471 & .93230 & 3.8235 & .80440\end{array}$

$9 \quad 3$

8 Lecturers and teachers participate in 85 guiding students
Exchanging, consulting and 85 adjusting the content of practicum, assessment of practicum

3.5059 .93380 $\begin{array}{lll}7 & 3.8118 & .77910\end{array}$

4 
9 Schools and pedagogical 85 universities often contact to discuss the situation of students

$3.3882 \quad 1.02463$

12

$3.6235 \quad 88609$

18

10 Discussing to unify the mechanism for the activities of stakeholders in practicum

85

$3.4118 \quad 95486$

$3.8471 \quad .68149$

10

1

85

$3.5176 \quad .94632$

$3.7647 \quad .78144$

5

9

85

$3.5176 \quad .94632$

$3.6706 \quad .80753$

5

14

85

$3.3529 \quad 93485$

$3.5647 \quad 90563$

18

20

$3.3882 \quad 1.02463$

$3.7765 \quad .79247$

12

85

$3.6000 \quad .91548$

$3.5882 \quad .90362$

1

19

85

$3.3882 \quad 1.05891$

$3.7647 \quad .81133$

12

9

$3.3765 \quad 1.02326$

$3.7882 \quad .78822$

17

7

$3.3882 \quad .95237$

$3.8471 \quad .79441$

12

$\begin{array}{lll}3.0824 & 1.00252 \quad 20\end{array}$

$3.6353 \quad .84300$

16

$3.1647 \quad 1.05613$

$3.6353 \quad .76915$

20 The schools often contact to discuss 85 the situation of the students

Through the table 7 shows that there are 4 content that is ranked in the number 1 position "Schools and pedagogical universities consider practicum as a process of connecting theories with practices."; "Schools and pedagogical universities agreed on the beginning and finishing timetable of practicum"; "The schools determine the student's result" (Mean $=3.600)$. All 3 evaluation criterions are carried out in both preparation and implementation practicum.

There are two contents that are assessed as not performing well such as: "Lecturers regularly visit schools" (Mean = 3.0824); "The schools often contact to discuss the situation of the students" (Mean = 3.1647) 
On the awareness of this relationship side, the items "Conference to improve the effectiveness of practicum" and "Discussing to unify the mechanism for the activities of stakeholders in practicum" reach the highest.

The contents that are assessed the lowest consisting of "The school determines the number of students based on the practical situation" (Mean = 3.5647); and "The schools determine the student's result" (Mean =3.5882)

\section{Discussion}

In pedagogical universities, students are equipped with theories about educational psychology, teaching skills and knowledge, specialized teaching methods. However, the teacher training process is effective when learning must get well with practice. The practicum is the process of applying theory to practice, forming professional capacity for students

The participant groups all have a basic understanding of the objectives, content and requirements of pedagogical practicum as well as the relationship between the pedagogical universities and the schools. Because the more awareness of the relationship between the school and pedagogical university in teacher training through pedagogical practicum, the more deeply they assess the situation. The research result ensures more reliable. Students are not fully awareness of the relationship between the school and pedagogical university, it is not close to reality when assesing. In contrast, lecturers are the group with the highest awareness, so the assessment of the degree of rigor will also be comprehensive and ensure more reliability.

The experience of guiding practicum in schools is not the same for all teachers; on the other hand, it is also possible that a part of the teachers who participated in the survey has not been assigned to instruct student teachers so observation and evaluation are more difficulties. In the process of implementing the practicum, the pedagogical universities develop programs, plans, practicum content then proceed to contact the schools to unify the plan. So the pedagogical university proactively develops programs and content plans for practice but also has the adjusted feedback from the schools. However, the beginning and the end of the practicum is agreed by the pedagogical university and the school in order to create favorable conditions for students to practice and does not affect the time of examination and assessment of student teacher.

The contents of the preparation have been coordinated smoothly by the schools and the pedagogical universities. The planning and implementation of practicum have been closely coordinated by the pedagogical university and the school. It has been bringing about the effective practicum. Based on the number of hours taught, the number of classes, the number of students will be determined. The pedagogical universities will adjust the number of interns for each delegation.

However, the contents belonging to the implementation are limited. The partnership between pedagogical universities and schools has to be improve. During practicum lecturers are not allowed to visit as well as observate student teaching at schools, therefore the regular exchange is also difficult. The student assessment process will usually be decided by the schools. The lecturers rated this content as not good. This has caused many limitations for pedagogical practicum. Lecturers only assign student teacher to school and visit during the practicum, They do not attend usually and not evaluate students members during the practicum. It is this that causes inadequacies, pedagogical lecturers have little time closely with interns, the exchange between theoretical lecturers and school instructors is rarely. It makes more difficulties in evaluating the results.

\section{Conclusion}

The partnership between pedagogical universities and schools on practicum is suitable to the Vietnamese context. This is reflected in preparation and planning process. It is play an vital role in contributing to good career development for students. In that relationship, pedagogical universities remain more active than schools. Feedback between two sides on issues related to pedagogical practice is unclear. In order to increase the active participation of schools in, it is necessary to actively change from the pedagogical universities to the awareness and actions of the schools'role. They need to focus on the "benefits" of schools and universities in the cooperation process. Schools should participate more active in the network of practicum schools. pedagogical universities need to create close coordination in terms of professional activities. The system of practical schools is really a condition for pedagogical universities to receive the fluctuations of educational practices, to update educational innovation, new educational policies. On the other hand, pedagogical universities have to identify one of their important tasks to improve the professional competence for teachers, the quality of teaching and educational activities for schools. Pedagogical universities can help schools foster teaching competencies for the teachers, update methods, modern teaching techniques and facilities. They also foster good teachers, good students ... These activities bring benefits to both sides. Schools improve the quality of teaching and educating students. Pedagogical universities improve the quality of training students. Because better professional 
is, the more quality of practicum is. Practicum is a compulsory content in teacher training programs in Vietnam. The importance of the problem has been specifically adopted by MOET through mandatory regulations for teacher training institutions. It is necessary to point out the two-side relationships with each other and assess those aspects with practical research. In order to carry out the role of guiding students closely to the educational environment in the most practical way, the schools have planned the timetable practicum in the annual plan; assign experienced teachers to guide students, create conditions for students to practice the teacher's work related to teaching and educational activities for students after contacting with the pedagogical universities. On the pedagogical institutions side, they are proactive in all stages of practicum process from time, place, student groups, instructing lecturers to guide the teacher student, promulgate documents and practicum rule with compulsory demand for schools.

\section{References}

Bernadette, L.D. in Farad, I. \& Jaworski, B. (Eds.). (2006). Partnerships in educational development. Oxford: Symposium Books, 69-82.

Bezzina, C., Lorist, P., Velzen, C.V. (2006). Partnerships between Schools and Teacher Education Institutes. Association of Teacher Education in Europe $31^{\text {st }}$ Annual ATEE conference, 747-58.

Brady, L. (2002). School University Partnerships: What Do the Schools Want?. Australian Journal of Teacher Education. 27(1), 1-9. https://doi.org/10.14221/ajte.2002v27n1.1

Braun, V. \& Clarke, V. (2006). Using thematic analysis in psychology. Qualitative Research in Psychology, 3(2), 77-101. https://doi.org/10.1191/1478088706qp063oa

Cain, T. (2009). Mentoring trainee teachers: How can mentors use research? Ment. Tutor, (17), 53-66. https://doi: $10.1080 / 13611260802233498$

Chu, A. (2017). Establish a partnership between pedagogy university school in teacher training. Journal of Science, Vinh University, Vietnam. Episode 46, Issue 3B, 5-11.

Clark, R.W. (1999). Effective professional development schools. San Francisco, CA: Jossey-Bass, Inc. Publishers.

Clarke, A., Triggs.V. \& Nielsen, W. (2014). Cooperating teacher participation in teacher education: A review of the literature. Rev. Educ. Res, 84, 163-202. https://doi: 10.3102/0034654313499618.

Creswell, J. W. (2012). Educational research: Planning, conducting, and evaluating quantitative and qualitative research. Boston, MA: Pearson.

David, E. L., Tony, Y. (2013). Teacher education in Australia: investigations into programming, practicum and partnership / Editors,. ISBN: 9781300831631 (Paperback) Subjects: Teachers--Training of--Australia. Oxford Global Press.

Duda, A. (2011). Teacher Education for Primary and Secondary Education in Six Countries of the Eastern Partnership: Armenia, Azerbaijan, Belarus, Georgia, Moldova and Ukraine. Final Report Agreement nr EAC-2011-0301 (Negotiated procedure EAC/28/2011) European Commission, Directorate-General for Education and Culture 22 September.

El-Amin, C., Cristol, D. \& Hammond, D. (2000). Constructing a professional development school: A model of one school-university partnership. The Teacher Educator, 1-14. https://doi.org/10.1080/08878739909555222

Fekadu, A., \& Melese, W. (2012). Partnership between teacher education institutes and secondary schools in Etiopia: Status, challenges, and prospect. Ethiop. J. Educ. \& Sc, 7(2), 43-60.

Foerste, E., Merler, A. \& Vargiu, A. (2017). Partnership in Teacher Education: A Theoretical and Practical Analysis. Creative Education, (8), 1275-1291. https://doi: 10.4236/ce.2017.88090

Gauthier, L. (2017). Developing an partnership in teacher preparation progam between colleges, universities and school districts: A policy advocacy document. https://digitalcommons.nl.edu/diss/248

Gravett, S., Petersen, N. \& Petker, G. (2014). Integrating foundation phase teacher education with a 'teaching school' at the University of Johannesburg. Educ. Change, 18, 107-119. https://doi: 10.1080/16823206.2013.877357

Greany, T. \& Brown, C. (2015). Partnership between teaching School and universities. Research report. http://www.scirp.org/journal/ce

Halasz, G. (2016). School-university partnership for effective teacher learning. ELTE Doctoral School of Education, May 13, 1-34. 
Handscomb, G., Gu, Q. \& Varley, M. (2014). School-University Partnerships: Fulfilling the Potential Literature Review. National Co-ordinating Centre for Public Engagement. Source:www.publicengagement.ac.uk.

Hartley, M. \& Huddleston. T. (2010). School-community-university partnerships for a sustainable democracy: Education for democratic citizenship in Europe and the United States of America. Council of Europe Publishing.

Hennissen, P., Crasborn, F., Brouwer, N., Korthagen, F. \& Bergen, T. (2011). Clarifying pre-service teacher perceptions of mentor teachers' developing use of mentoring skills. Teach. Teach. Educ, 27, 1049-1058. https://doi: 10.1016/j.tate.2011.03.009

Hill. A. (2008). Learning in the workplace: new forms of learning for preservice teachers, in Kell, P., Vialle, W., Konza, D. \& Vogl, G. (eds), Learning and the learner: exploring learning for new times. University of Wollongong.

Hobson, A. J. (2002). Student teachers' perceptions of school-based mentoring in initial teacher training (ITT). Ment.Tutor, 10, 5-20. https://doi: 10.1080/13611260220133117

Holen, M. C. \& Yunk, D.C. (2014). Benefits of 25 Years of School District-University Partnerships to Improve Teacher Preparation and Advance School Renewal. Educational Considerations, 42(1), 49-54. https://doi.org/10.4148/0146-9282.1045

Jones, M. M. (2008). Collaborative Partnerships: A Model for Science Teacher Education and Professional Development. Australian Journal of Teacher Education, 33(3), 61-76. https://doi.org/10.14221/ajte.2008v33n3.5

Jones, M. et all. (2016): Successful university-school partnerships: an interpretive framework to inform partnership practice. Teach. Teach. Educ, 60, 108-120. https://doi: 10.1016/j.tate.2016.08.006

Keogh et all. (2006). Supervisor or mentor? Questioning the quality of pre-service teacher practicum experiences. AARE International Education Research Conference. http://hdl.handle.net/10072/93275

Kertesz, J. L. \& Downing. J. (2016). Piloting Teacher Education Practicum Partnerships: Teaching Alliances for Professional Practice (TAPP). Australian Journal of Teacher Education, 41(12). 13-24. https://ro.ecu.edu.au/ajte/vol41/iss12/2

My, G.S. (2014), Managing pedagogical practicum in training high school teachers under the orientation of high school teachers' professional standards. Doctoral thesis in education management. Hanoi National University of Education.

Quick. G., Siebörger. R., (2005). What matters in practice teaching? The perceptions of schools and students. South African Journal of Education. EASA, 25(1), 1-4.

Magudu. S. \& Gumbo. M.T. (2018). Efficacy of the partnership between teacher education instutions and primary school in teacher preparation in Zimbabwe. South African Journal of Higher Education, 32(5), 104-123. http://doi.org/10.20853/32-5-2595

Sigurdardóttir, A. K. (2010). School-university partnership in teacher education for inclusive education. Journal of Research in Special Educational Needs, 10(1), 149-156. https://doi:10.1111/j.1471-3802.2010.01160.x

Singh. P. \& Mahomed. C. (2013). The Value Of Mentoring To Develop Student Teachers' Work-Integrated Learning Skills. International Business \& Economics Research Journal, 12(11), 1373-1388. https://doi.org/10.19030/iber.v12i11.8175

Smith. K. (2016). Partnerships in Teacher Education - Going Beyond the Rhetoric. Reference to the Norwegian Context. e.p.s.s Journal, 6(3), 7-36.

Velzen, V. C. \& Volman. M. (2008). School-based teacher educators in the Netherlands and the opportunities of the school as a learning place. ISCAR,1-20. 